\title{
Overview of weed management in garlic in Poland
}

\section{Analiza możliwości regulacji zachwaszczenia w uprawach czosnku w Polsce}

\author{
Ewa Matyjaszczyk ${ }^{1 *}$, Adam Dobrzański $^{2}$
}

\section{Summary}

Garlic is susceptible to weeds and is an example of the crop where integrated weed management seems to be the most effective protection solution. Due to the large number of small farms in Poland, production of minor crops, including garlic, has great importance, as it allows achieving a relatively high income per hectare. The paper presents both the non-chemical and chemical methods of garlic protection against weeds. The non-chemical weed management is usually not sufficient on large plantations. On the other hand too strong dependence on chemical weed control is also not viable solution in garlic protection. Therefore for optimal results the chemical and non-chemical methods should complement each other. The availability of plant protection products for weed control in Poland is limited to prosulfocarb, pendimethalin, propaquizafop, fluazifop P-butyl and quizalofop-P-ethyl. The availability of herbicides registered for garlic protection in other European Union Member States is also limited but usually better than in Poland.

Key words: garlic; weeds; herbicide; weed management; minor crops; integrated pest management

\section{Streszczenie}

Czosnek jest podatny na zachwaszczenie i stanowi przykład uprawy, w której integrowana ochrona przed chwastami jest rozwiązaniem najbardziej efektywnym. Ze względu na dużą liczbę niewielkich gospodarstw, produkcja upraw małoobszarowych, a wśród nich czosnku, ma w Polsce spore znaczenie, ponieważ pozwala na osiągnięcie stosunkowo wysokiego przychodu z hektara uprawianej powierzchni. W pracy przedstawiono zarówno niechemiczne, jak i chemiczne metody ochrony czosnku przed chwastami. Na dużych plantacjach metody niechemiczne są zwykle niewystarczające. Z drugiej strony stosowanie wyłącznie ochrony chemicznej także nie sprawdza się w ochronie czosnku. Dla uzyskania optymalnego rezultatu metody chemiczne i niechemiczne powinny wzajemnie się uzupełniać. Dostępność środków chwastobójczych w Polsce jest ograniczona do prosulfokarbu, pendimetaliny, propachizafopu, fluazyfopu P-butylowego oraz chizalofopu-P-etylowego. Dostępność herbicydów zarejestrowanych do ochrony czosnku w innych państwach członkowskich Unii Europejskiej jest także ograniczona, ale zwykle lepsza niż w Polsce.

Słowa kluczowe: czosnek; chwasty; herbicydy; zwalczanie chwastów; uprawy małoobszarowe; integrowana ochrona roślin

\footnotetext{
Instytut Ochrony Roślin - Państwowy Instytut Badawczy

Władysława Węgorka 20, 60-318 Poznań

${ }^{2}$ Instytut Ogrodnictwa

Konstytucji 3 Maja 1/3, 96-100 Skierniewice

*corresponding author: e.matyjaszczyk@iorpib.poznan.pl
} 


\section{Wstęp / Introduction}

Czosnek jest popularnym w Polsce warzywem o różnorodnym przeznaczeniu (Doruchowski 2006), często uprawianym w ogrodach przydomowych. Istnieją jednak w naszym kraju wyspecjalizowane gospodarstwa, dla których uprawa czosnku jest ważnym lub głównym źródłem dochodu. Plantacje takie zlokalizowane są głównie w Małopolsce (Słomniki, Radziemice), na Dolnym Śląsku, w okolicach Zamościa, Zielonej Góry, Poznania, Kutna i Łęczycy oraz Warszawy (Nowy Dwór, Błonie, Ożarów). W Polsce uprawia się czosnek na powierzchni ponad 3000 ha, a jego produkcja wynosi rocznie około 15-20 tysięcy ton. Krajowa produkcja nie pokrywa w całości zapotrzebowania na to warzywo i dlatego jest importowany z innych krajów.

Dane GUS wskazują na pewną prawidłowość: przeciętnie im mniejsza powierzchnia gospodarstwa, tym większy odsetek jego powierzchni jest przeznaczany pod uprawę warzyw, owoców oraz ziemniaków (GUS 2012). Największy odsetek gospodarstw, w których uprawia się warzywa gruntowe znajduje się wśród tych, dla których głównym źródłem utrzymania jest zarówno działalność rolnicza, jak i praca najemna (GUS 2014), czyli wśród tych, którym przychody z działalności rolniczej nie wystarczają na utrzymanie. Wynika to między innymi $\mathrm{z}$ faktu, że koncentrując się na produkcji gatunków wymagających dużego nakładu pracy (takich jak owoce, warzywa czy niektóre rośliny ozdobne) można liczyć na uzyskanie stosunkowo wysokiego przychodu $\mathrm{z}$ hektara uprawianej powierzchni. Jest to istotne, biorąc pod uwage niewielkie przeciętne przychody uzyskiwane w małych gospodarstwach $\mathrm{z}$ działalności rolniczej $\mathrm{i}$ wysoki dysparytet dochodowy cechujący gospodarstwa rolnicze o różnym obszarze (Chmielewska 2011).

Efekty finansowe produkcji roślin małoobszarowych zależą od roku i od uprawy. Z kalkulacji Ośrodków Doradztwa Rolniczego wynika, że uprawa czosnku jest opłacalna, a jej wskaźnik opłacalności w ostatnich latach był dość wysoki (Mazowiecki Ośrodek Doradztwa Rolniczego 2016). Przeznaczenie części posiadanych gruntów pod uprawę czosnku, może zatem stanowić sposób na poprawę dochodowości gospodarstwa rolnego. Obecnie w Polsce, podobnie jak w innych państwach członkowskich Unii Europejskiej obowiązkowe jest stosowanie integrowanej ochrony roślin. Wymaga ona stosowania między innymi metod prewencyjnych, w tym niechemicznych, dlatego niektóre badania wskazują, że koszty jej stosowania są nieco wyższe (Golinowska 2012). Rolnicy prowadzący niewielkie gospodarstwa rolne nie zawsze właściwie rozumieją pojęcie ,integrowana ochrona roślin” (Paszko i wsp. 2015), jednak metody niechemiczne są przez nich często stosowane.

Celem niniejszego opracowania było przedstawienie dostępnych w Polsce możliwości ochrony czosnku przed chwastami, zarówno chemicznych, jak i niechemicznych.

\section{Problem zachwaszczenia plantacji czosnku / Problem of weeds in garlic}

W integrowanej ochronie przed chwastami system wspomagania decyzji o ich zwalczaniu zaleca się opierać na rozpoznaniu składu gatunkowego flory segetalnej i dynamiki pojawiania się poszczególnych taksonów zależnie od rodzaju gleby i innych uwarunkowań agroekologicznych (Rola i wsp. 1999; Domaradzki i wsp. 2003).

Czosnek sadzi się do gleby wiosną lub jesienią. Czosnek wiosenny sadzi się wcześnie wiosną, nie później niż do 10 kwietnia. Jesienią czosnek jest sadzony w trzeciej dekadzie października, aby rośliny przed zimą ukorzeniły się, ale nie wytworzyły liści. Jeśli długo utrzymuje się temperatura około $10^{\circ} \mathrm{C}$, liście mogą wyrosnąć. Sprzyjają temu też łagodne zimy. Gdy przed nadejściem mrozów rośliny z wyrośniętymi liśćmi nie są zakryte śniegiem, czosnek może wymarznąć - uszkadza je wówczas nawet krótkotrwały mróz (Doruchowski 2006).

Niezależnie od terminu sadzenia, czosnek podobnie jak inne warzywa cebulowe, jest wrażliwy na konkurencję chwastów szczególnie w początkowych fazach wzrostu (Duranti 1988; Quasem 1996; Rahman i wsp. 2012), gdyż tworzy wąskie liście, słabo zakrywające glebę. Dlatego niezniszczone $\mathrm{w}$ porę chwasty łatwo rozrastają się na plantacjach czosnku obniżając jego plon (Agamalian i Kurtz 1989). Odchwaszczanie jest zatem zabiegiem bardzo istotnym. W badaniach przeprowadzonych w Skierniewicach (Dobrzański i wsp. 2003) stwierdzono, że na plantacji czosnku z jesiennego terminu sadzenia, na której nie usunięto chwastów wczesną wiosną, a dopiero w pierwszej, drugiej dekadzie maja, świeża masa chwastów wynosiła 4,5 t/ha (średnia z kilku lat obserwacji) i - w zależności od roku i gatunków chwastów - mieściła się granicach od 1,9 do 7,5 t/ha. Natomiast na nieodchwaszczanej plantacji czosnku sadzonego wiosną, po około 6 tygodniach od sadzenia masa ta wynosiła średnio $8,4 \mathrm{t} /$ ha $(2,1-20,7 \mathrm{t} / \mathrm{ha})$. Na wytworzenie takiej masy chwasty zużyły duże ilości składników pokarmowych, pogarszając ogólne warunki wzrostu roślin czosnku.

Czosnek ma duże wymagania wilgotnościowe, stąd zagrożenie ze strony chwastów jest większe w okresach suszy, gdy nie ma możliwości nawadniania. Niezależnie od terminu sadzenia najgroźniejsze są chwasty pojawiające się od wczesnej wiosny do końca maja, aczkolwiek lepiej jest utrzymywać plantację bez chwastów aż do zbioru. Na zachwaszczonym polu istnieje większe ryzyko wystąpienia chorób, a czosnek osiąga dojrzałość później i gorzej się dosusza. Jeżeli w uprawie czosnku nie stosuje się herbicydów konieczne jest kilkakrotne, mechaniczne odchwaszczanie (Orłowski i Kołota 1993). Z badań Barańskiej i Sabat (1988), wynika że nakłady pracy na odchwaszczanie czosnku zależą od stopnia mechanizacji i mogą przekraczać nawet $800 \mathrm{rbg} / \mathrm{ha}$. Aby zminimalizować straty w plonie, plantacja powinna być wolna od chwastów od wznowienia wegetacji po zimie, a w uprawie czosnku sadzonego wiosną od początku wschodów przynajmniej przez 5-8 tygodni. Zachwaszczenie w tym czasie przez 30 dni obniża plon o około $30 \%$, a uprawa bez odchwaszczania o 60-80\% (Agamalian i Kurtz 1989; Quasem 1996).

W uprawie czosnku mogą występować różne gatunki chwastów, przy czym nasilenie ich pojawiania się uzależnione jest od terminu uprawy. Wykonano wiele obserwacji fitosocjologicznych nad rozmieszczeniem i występowaniem chwastów w wielkoobszarowych roślinach rolniczych (Rola i wsp. 1999; Rola i Rola 2013). Dla czosnku brak jest 
udokumentowanych badań, aczkolwiek w przypadku warzyw rozeznanie jest dość dobre (Dobrzański 1999; Siciński 2000). Inny może być skład gatunkowy chwastów w czosnku sadzonym jesienią, a nieco inny wiosną.

$\mathrm{W}$ uprawie $\mathrm{z}$ jesiennego terminu wyróżnia się dwa okresy pojawiania się chwastów: pierwszy - od sadzenia i wystąpienia pierwszego silnego mrozu do końca zimy; drugi - od wczesnej wiosny następnego roku, gdy chwasty kiełkują i wschodzą do czasu zbioru. Późną jesienią, gdy czosnek nie wytworzył jeszcze liści i na początku ich wyrastania, chwasty nie są groźne, pod warunkiem, że nie przezimują. Zachwaszczony czosnek jest słabszy i w okresie zimowym może być łatwiej uszkadzany przez mróz, jeżeli chwasty nie wymarzną. W uprawie czosnku sadzonego jesienią dominują chwasty dwuliścienne. Największe straty powodują te, które przezimowały i wschodzące wczesną wiosną. Podczas długiej i ciepłej jesieni mogą wzejść zimujące i ozime gatunki chwastów (np. chaber bławatek, fiołek polny, tasznik pospolity, tobołki polne, jasnoty, gwiazdnica pospolita, przytulia czepna, starzec zwyczajny, rumiany i rumianki), zimujące w fazie rozetek liściowych. Z chwastów jednoliściennych często w czosnku spotykana jest wiechlina roczna i owies głuchy. Część chwastów wschodzących późną jesienią może wymarznąć, ale wiosną pojawiają się ponownie, szczególnie po pierwszym mechanicznym wzruszeniu gleby w międzyrzędziach. W niektórych latach obniżona temperatura jesienią po sadzeniu i późniejsze ocieplenie mogą spowodować kiełkowanie chwastów na przełomie listopada i grudnia. Gdy nie ma śniegu i zimą występują okresowe ocieplenia, ich kiełkowanie i wschody można zaobserwować przez cały grudzień i w pierwszej oraz drugiej dekadzie stycznia. Niektóre chwasty, zwłaszcza starzec pospolity, tasznik pospolity i tobołki polne mogą być nieznacznie uszkadzane przez mróz, ale po wiosennym ociepleniu błyskawicznie się regenerują. Gatunki te mogą wschodzić także wiosną, ponieważ cechują się szerokim zakresem temperatur wymaganych do kiełkowania (Lauer 1953; Markow 1978; Dobrzański 2008).

Wiosną, niezależnie od terminu sadzenia szybko wschodzą: komosa biała, przytulia czepna, dymnica pospolita, gorczyca polna, rdesty, blekot pospolity, bodziszek drobny, pokrzywa żegawka, przetaczniki, wilczomlecz obrotny czy poziewnik szorstki. Gdy jest cieplej, pojawia się żółtlica drobnokwiatowa i owłosiona, szarłat szorstki i psianka czarna, a z chwastów jednoliściennych - włośnica zielona i chwastnica jednostronna. Gatunki te są też najczęściej wymieniane w publikacjach polskich, w których przedstawiono wyniki badań skuteczności biologicznej herbicydów badanych w czosnku (Fajkowska i Dobrzański 1970; Orłowski i Kołota 1983; Pałczyński i Dobrzański 1993). Na stanowisku po zbożach lub po przyoraniu mieszanki żyta $\mathrm{z}$ wyką, czosnek może być zachwaszczony samosiewami zbóż. Czasem występuje miotła zbożowa.

Należy unikać uprawy czosnku na polach zachwaszczonych gatunkami wieloletnimi (tzw. chwastami trwałymi). Gleby zalecane do uprawy czosnku sprzyjają występowaniu m.in.: rzepichy leśnej, rdestu ziemnowodnego, czyśćca błotnego, mięty polnej i perzu. Powinno się unikać uprawy czosnku także na polach zachwaszczonych ostrożeniem polnym, powojem polnym, mleczem polnym czy skrzypem polnym. Trudno jest usunąć je w okresie wegetacji. Dlatego pod uprawę czosnku należy wybierać stanowiska po roślinach wcześnie wschodzących z pola, aby przed sadzeniem był czas na ograniczenie zachwaszczenia zabiegami agrotechnicznymi i chemicznymi.

\section{Niechemiczne sposoby ograniczania zachwaszczenia / Non-chemical weed control}

Zachwaszczenie gatunkami jednorocznymi zmniejsza uprawa $\mathrm{w}$ plonie głównym, jako międzyplon lub poplon ścierniskowy przeznaczonych na przyoranie $w$ postaci nawozu zielonego mieszanek $\mathrm{z}$ dużym udziałem roślin bobowatych grubonasiennych (wyka, peluszka, łubin), z wyjątkiem bobu i bobiku. Mogą to być też gorczyca biała, rzodkiew oleista, facelia, żyto ozime i gryka. Jedną z metod zapobiegania zachwaszczeniu jest ściółkowanie gleby czarną folią, agrowłókniną, ściółkami organicznymi pochodzenia roślinnego (np. rozdrobniona słoma, skoszone części nadziemne mieszanek traw i roślin bobowatych) oraz z roślin okrywowych wysiewanych latem lub jesienią poprzedniego roku, jako międzyplon ścierniskowy i niszczonych mechanicznie lub chemicznie albo wykładanych w międzyrzędziach po sadzeniu ząbków (Rumpel i Grudzień 1984; Teasdale i wsp. 1991; Kotliński 2004; Dobrzański i Anyszka 2006; Babik i wsp. 2015). Najczęściej wykorzystywana jest czarna folia lub czarne agrowłókniny o różnych szerokościach. W przecięcia ściółek z czarnej folii lub agrowłókniny sadzone są ząbki czosnku. Jest to skuteczny sposób ograniczania zachwaszczenia. Jednak metoda ta nie zawsze jest wystarczająca. W przecięciach foli i włóknin, obok roślin czosnku mogą wyrastać chwasty, które należy usuwać ręcznie. Pozostaje też pomiędzy zakrytymi pasami reszta odsłoniętego pola, gdzie chwasty trzeba usuwać jedną z dostępnych metod, najczęściej mechanicznie lub ręcznie.

Ściółkowanie materiałami organicznymi (np. korą drzew iglastych, kompostem, rozdrobnioną i częściowo rozłożoną słomą), zalecane głównie do ochrony przed wymarzaniem, także w pewnym stopniu ogranicza zachwaszczenie (Doruchowski 2006). Występowanie chwastów jednorocznych skuteczniej zmniejsza podwójne ściółkowanie, polegające na usunięciu wiosną ściółki z rozdrobnionej słomy położonej jesienią, wykonaniu płytkiej uprawki międzyrzędowej i ponownym położeniu ściółki. Ściółkowanie jest zalecane w uprawie prawie wszystkich warzyw, włącznie z czosnkiem, aczkolwiek nie można znaleźć wyników polskich badań potwierdzających przydatność tej metody w jego uprawie. Wiadomo jednak, że jest w praktyce wykorzystywana głównie w uprawach ekologicznych i na małych plantacjach.

W okresie wegetacji czosnku zwalczanie chwastów polega na mechanicznym odchwaszczaniu i ręcznym pieleniu. Jesienią po sadzeniu, zniszczenie chwastów zabiegami mechanicznymi może być utrudnione przez deszcz i wysoką wilgotność gleby uniemożliwiające wprowadzenie na pole narzędzi. Wiosną, zanim gleba po zimie przeschnie, tak aby można było wykonać na polu zabiegi mechaniczne i ręczne pielenie, gatunki które przezimowały zdążą się silnie ukorzenić i stają się trudne do usunięcia. Wiosną dobrze jest wzruszyć zbitą glebę 
przez 2-3-krotne spulchnienie międzyrzędzi. Zabiegi powinny być zakończone zanim rośliny zaczną formować główki. Należy je prowadzić jak najpłycej, żeby nie przesuszać gleby i nie wyciągać na jej powierzchnię nasion chwastów z głębszych warstw, a także aby nie uszkodzić korzeni czosnku. Łatwiej jest odchwaszczać czosnek posadzony w szerszych międzyrzędziach, np. co 30-45 cm (Orłowski i Kołota 1984), zwłaszcza gdy używane są noże kątowe i gęsiostópki. Powinny one wzruszać glebę w odległości nie mniejszej niż $5 \mathrm{~cm}$ od czosnku.

Po mechanicznym odchwaszczaniu, gdy nie stosuje się herbicydów, może być konieczne pielenie ręczne w rzędach. Do mechanicznego zwalczania chwastów można korzystać z różnych narzędzi (Bond i Grundy 2001; Adamczewski i Dobrzański 2008; Van der Weide i wsp. 2008; Dobrzański i Adamczewski 2013; Zbytek i Talarczyk 2013; Żelaziński 2014). Oprócz od dawna używanych noży kątowych w połączeniu z gęsiostópkami i wałkami strunowymi zalecane są pielniki szczotkowe i pielniki palcowe wyposażone w gwiazdy pielące. Pielnik palcowy jest nazwą tłumaczoną $\mathrm{z}$ języka angielskiego (finger weeder). W Polsce przyjęta jest też nazwa pielniki gwiazdowe. Pozwalają one na usuwanie chwastów rosnących bardzo blisko uprawianych roślin. Można je wprowadzać w międzyrzędzia, wcześnie po wschodach chwastów, gdy czosnek jest dobrze ukorzeniony. Gwiazdy pielące mają różną szerokość roboczą i są najczęściej zagregatowane, jako narzędzia wielofunkcyjne $\mathrm{z}$ wałkami strunowymi, nożami kątowymi lub innymi narzędziami. Można też termicznie zwalczać chwasty wypalarkami (wypalaczami gazowymi) spalającymi gaz z butli przed sadzeniem, przed wschodami lub po sadzeniu w międzyrzędziach (Ascard 1995; Adamczewski i Dobrzański 2008). Urządzenia do termicznego zwalczania chwastów są dostępne w naszym kraju (Termopielnik 2016). Wysoka temperatura powoduje rozrywanie tkanek wschodzących chwastów oraz niszczenie wierzchołka wzrostu, w wyniku czego roślina ginie. Ta metoda ogranicza stosowanie herbicydów i jest polecana $\mathrm{w}$ integrowanej oraz ekologicznej uprawie. Jej zaletą jest możliwość niszczenia chwastów, gdy gleba jest zbyt wilgotna i utrudnia zabiegi mechaniczne. Korzystne jest też nie wzruszanie gleby, co zmniejsza ponowne pojawianie się chwastów. Wadą tej metody jest niszczenie tylko nadziemnych części chwastów, które mogą odrastać. Dotyczy to szczególnie chwastów wieloletnich odrastających z korzeni i rozłogów (np. perz, ostrożeń polny). Efekt metody termicznej jest krótkotrwały, nie dłuższy niż po zastosowaniu $\mathrm{w}$ tym terminie nalistnie działających herbicydów zawierających glifosat.

Wiele chwastów można zniszczyć, stosując cyjanamid wapnia w formie nawozu Perlka. W zależności od dawki uszkadza kiełkujące nasiona chwastów nie gorzej niż niektóre herbicydy. Należy go stosować w dawce 300-600 kg/ha, w terminie 2-3 tygodni przed sadzeniem.

\section{Przedplon i herbicydy w przedplonie / Forecrop and herbicides in the forecrop}

Nie wszystkie gatunki roślin nadają się jako przedplon dla czosnku. Warto jednak zwrócić uwagę na fakt, że czosnek uprawiany po roślinach, w których aplikowano długo działające w glebie herbicydy, jest mniej zachwaszczony. Nie można także zapominać o tym, że niektóre dłużej działające substancje czynne herbicydów mogą być dla czosnku fitotoksyczne. Ze względów fitosanitarnych, a szczególnie ze względu na ryzyko porażenia przez nicienie, nie należy sadzić czosnku po warzywach korzeniowych (np. po marchwi, pietruszce, selerze) oraz ziemniaku, rzepaku i innych kapustowatych, grochu, bobie i bobiku (Doruchowski 2006), pomimo tego że niektóre z nich można odchwaszczać skutecznie działającymi herbicydami. Niektóre środki stosowane w przedplonach działają długo w glebie i mogą źle wpływać na wzrost czosnku. Okres rozkładu do $90 \%$ początkowej zawartości trwa w przypadku niektórych substancji czynnych nawet kilka miesięcy (PPDB - Pesticides Properties Data Base 2016). Po ogórku odchwaszczanym chlomazonem i mieszaninami chlomazonu z innymi substancjami czynnymi, lepiej nie uprawiać czosnku jesienią, bo mogą wystąpić uszkodzenia i zahamowanie wzrostu. Do dobrych stanowisk dla czosnku zaliczane jest pole po uprawie pomidora, ale po nim i innych roślinach odchwaszczanych metrybuzyną czosnek zaleca się sadzić nie wcześniej niż po 12-14 tygodniach od zastosowania środka.

Za dobre stanowisko dla czosnku uznawane są pola po odchwaszczonych zbożach, z wyjątkiem owsa. Jednak po użyciu w nich długo działającego w glebie chlorosulfuronu i sulfosulfuronu, lepiej czosnku nie sadzić. Do lepszych przedplonów należą koniczyna i lucerna. Jeżeli były one odchwaszczane herbicydami zawierającymi propyzamid, wtedy czosnek można sadzić nie wcześniej niż po 7 miesiącach od zastosowania środka. Należy też unikać uprawy po kukurydzy odchwaszczanej mezotrionem, niezależnie od tego czy występował on jako jedyna substancja czynna herbicydów czy w mieszaninie $\mathrm{z}$ innymi. Nie stwarza problemów następcze działanie s-metolachloru zalecanego w kukurydzy i bentazonu zalecanego w fasoli oraz linuronu stosownego w kukurydzy. Czosnek można uprawiać po różnych roślinach odchwaszczanych długo działającą w glebie pendimetaliną. Niektóre informacje o następczym działaniu herbicydów są w ich etykietach, ale o czosnku się w nich nie wspomina. Brak jest też dobrze udokumentowanych polskich badań tego typu.

\section{Możliwości ochrony chemicznej czosnku przed chwastami w Polsce / Possibilities of chemical protection of garlic against weeds in Poland}

Mimo, że metody niechemiczne są wykorzystywane $\mathrm{w}$ praktyce to $\mathrm{w}$ uprawie czosnku nie są one zwykle wystarczające. Nie wynika to jedynie z kosztów i czasochłonności, ale także z tego, że przy dużej wilgotności gleby wykonanie uprawek międzyrzędowych i ręczne pielenie często nie jest fizycznie możliwe do wykonania. $\mathrm{Z}$ tego powodu producenci chętnie sięgają po herbicydy, które można aplikować jesienią po sadzeniu ząbków lub wczesną wiosną.

Obserwacje z praktyki i badania wielu autorów wskazują, że ze względu na bardzo dużą wrażliwość czosnku na konkurencję, sama chemiczna ochrona także nie jest wys- 
tarczająca. Oprócz aplikacji herbicydów konieczne są uzupełniające zabiegi niechemiczne, bowiem żaden obecnie zalecany w różnych krajach herbicyd nie wystarcza, aby utrzymać plantację wolną od chwastów dostatecznie długo. Rahman i wsp. (2012) podają, że najwyższe plony czosnku zapewniało zastosowanie herbicydu zawierającego 33\% pendimetaliny i dwukrotne pielenie po 30 i 60 dniach po wschodach czosnku.

Zgodnie z danymi Ministerstwa Rolnictwa i Rozwoju Wsi (Wyszukiwarka 2016) w listopadzie 2016 roku do odchwaszczania czosnku można było stosować łącznie 7 środków ochrony roślin zawierających prosulfokarb, pendimetalinę, propachizafop, fluazyfop P-butylowy oraz chizalofop-P-etylowy. Dla skutecznego regulowania poziomu zachwaszczenia trzeba dysponować kilkoma herbicydami.

W wyspecjalizowanych w uprawie czosnku gospodarstwach bywa on często uprawiany w zmianowaniu. Przy niewielkiej liczbie herbicydów są ograniczone możliwości przemiennego ich stosowania i takie same substancje czynne używane są często w zmianowaniu. Może to spowodować masowy wzrost liczby gatunków niezwalczanych przez określony herbicyd albo pojawienie się biotypów uodpornionych. Zjawisku temu zapobiega przemienne stosowanie środków o różnym mechanizmie działania (Matthews 1994; Adamczewski 2014). Podstawowym herbicydem o szerokim zakresie niszczonych gatunków jest pendimetalina, zalecana po sadzeniu, przed wschodami czosnku lub po wschodach w fazie 2 liści. W 2016 roku dostępne były dwa środki o różnej zawartości substancji czynnej i różnej maksymalnej, dozwolonej dawce. Herbicydy te najlepiej niszczą chwasty jednoroczne w okresie kiełkowania i wschodów; jednoliścienne do początku drugiego liścia właściwego, dwuliścienne do 2 liści. Należy unikać aplikacji, gdy temperatura gleby i powietrza wynosi poniżej $5^{\circ} \mathrm{C}$, bo środek może działać słabiej. Ząbki czosnku powinny być posadzone na głębokość 5-8 cm, zwłaszcza na lżejszych glebach. W celu poprawienia skuteczności i zmniejszenia ryzyka uszkodzeń, przed wschodami czosnku wskazany jest dodatek adiuwantów wielofunkcyjnych zalecanych do stosowania z herbicydami działającymi doglebowo (Kucharski 2015), mianowicie: Atpolan Soil 80 EC, Atpolan Soil Maxx 0,3-0,6 1/ha lub Grounded - 0,2-0,4 1/ha. Przy ściółkowaniu, np. rozdrobnioną słomą, na kilka dni przed położeniem ściółki można opryskiwać wilgotną glebę. Po wschodach czosnku, w fazie 1-2 liści, preparaty zawierające pendimetalinę stosuje się wiosną po rozmarznięciu gleby i usunięciu ściółki. Jeżeli chwasty przezimowały oraz gdy po zimie powierzchnia gleby jest zaskorupiała, zabieg należy wykonać po spulchnieniu międzyrzędzi. Warto podkreślić, że do etykiety jednego z preparatów zawierających pendimetalinę prawdopodobnie wkradł się błąd, gdyż zaleca stosowanie preparatu po siewie. Czosnku nie uprawia się z nasion, lecz rozmnaża się wegetatywnie, sadząc ząbki uzyskane $\mathrm{z}$ podziału główek. Uprawne biotypy czosnku (tzw. odmiany strzałkujące) wybijają w pędy kwiatostanowe i kwitną, ale nie tworzą nasion zdolnych do kiełkowania, lecz małe cebulki powietrzne (Kotlińska 1993; Doruchowski 2006). Nie są one wykorzystywane do sadzenia $\mathrm{w}$ towarowej produkcji, lecz sporadycznie w uprawie amatorskiej, gdzie nie ma potrzeby stosowania herbicydów.

Do zwalczania chwastów rocznych, głównie dwuliściennych, przed wschodami i wcześnie po wschodach (do 2-3 liści), w fazie 1-2 liści czosnku można użyć preparat zawierający prosulfokarb. Aplikuje się go wiosną po rozmarznięciu gleby. Gdy po zimie gleba jest zaskorupiała, zabieg najlepiej wykonać po płytkim, mechanicznym spulchnieniu międzyrzędzi. Deszcz lub nawadnianie w godzinę po zabiegu nie obniżają skuteczności, ale prosulfokarbu nie należy stosować na rośliny wilgotne. Może on powodować przemijające uszkodzenia liści czosnku. Na środek ten jest odporna chwastnica jednostronna i perz. Perz i roczne chwasty jednoliścienne można zniszczyć po wschodach czosnku jednym z graminicydów. Stosuje się je wiosną uzupełniająco, po herbicydach zwalczających chwasty dwuliścienne. Może to być jeden z dwóch środków zawierających fluazyfop-P-butylowy. Dawki zależą od zaleceń w etykiecie preparatu, a także gatunku i fazy wzrostu chwastów; niższe zwalczają chwastnicę jednostronną i inne chwasty roczne, $z$ wyjątkiem wiechliny rocznej, zaś wyższe perz i wiechlinę. Roczne chwasty jednoliścienne są wrażliwe od 2 liści do krzewienia, a perz w fazie 4-10 liści. Do ochrony czosnku przed chwastami jednoliściennymi zalecany jest też jeden preparat zawierający chizalofop-P-etylowy. Zwalcza on tylko roczne gatunki jednoliścienne: chwastnicę jednostronną i włośnice. Rekomendowanych dawniej dawek niszczących perz nie można zalecać i stosować.

Warto podkreślić, że każdy środek ochrony roślin należy stosować zgodnie $\mathrm{z}$ etykietą - instrukcją stosowania. Ze środków zawierających wymienione wyżej substancje czynne należy wybrać te, w których etykietach uwzględniony jest czosnek. Jeżeli etykieta danego preparatu nie wymienia czosnku, to nie można go w tej uprawie stosować nawet na własną odpowiedzialność. Warto także zaznaczyć, że po zabiegu środkiem zawierającym pendimetalinę, stosowanie graminicydów nie zawsze jest konieczne, zwłaszcza gdy na polu występuje głównie chwastnica jednostronna.

\section{Możliwości chemicznej ochrony czosnku w innych krajach / Possibilities of garlic chemical protection in other countries}

Ze względu na duże znaczenie czosnku na świecie FAO (Food and Agriculture Organisation of United Nations - Organizacja Narodów Zjednoczonych do spraw Wyżywienia i Rolnictwa) wydała publikację dotyczącą czosnku (FAO 2007). Została ona poświęcona przede wszystkim zagadnieniu prawidłowego zbioru i przechowywania oraz właściwościom leczniczym czosnku, ale uwzględnia również zalecenia chemicznej ochrony. Do ochrony przed chwastami zaleca 7 substancji czynnych, z których tylko niektóre są dopuszczone do stosowania w Unii Europejskiej. Do stosowania przedwschodowego publikacja zaleca bensulid, DCPA oraz parakwat (żadna $\mathrm{Z}$ tych trzech substancji nie jest dopuszczona do stosowania na terenie Unii Europejskiej). Do stosowania zarówno przedwchodowego, jak i powschodowego zaleca 
bromoksynil, a do stosowania powschodowego kletodym, fluazyfop-P oraz setoksydym (setoksydym nie jest dopuszczony do stosowania w Unii Europejskiej).

W 2016 roku w Niemczech do ochrony czosnku przed chwastami dostępnych było 49 herbicydów, zawierających m.in. glifosat, pendimetalinę, dimetenamid-P, prosulfokarb, flufenacet, bromoksynil, chlopyralid, pirydat, fluroksypyr, cykloksydym, fluazyfop-P-butyl, kwas pelargonowy. W Wielkiej Brytanii do chemicznej ochrony czosnku można stosować linuron, tepraloksydym, bentazon, chlorydazon, s-metolachlor, propachizafop oraz środek zawierający dwie substancje czynne: dimetenamid-P + pendimetalinę. W Czechach w roku 2016 zalecano ponad 20 preparatów handlowych zawierających: acklonifen, pendimetalinę, chizalofop-P-etylowy (Databases 2016).

W Polsce ostatnie badania skuteczności biologicznej uzasadniającej rejestrację herbicydów dla czosnku prowadzono w latach 1965-1967 i 1988-1990 (Fajkowska i Dobrzański 1970; Dobrzański 1988; Pałczyński i Dobrzański 1993). Wykazano w nich, że czosnek można odchwaszczać między innymi zalecanymi w Wielkiej Brytanii środkami zawierającymi linuron i fluazyfop-P-butylowy oraz pendimetalinę i oksyfluorofen, a także innymi substancjami czynnymi obecnie niedopuszczonymi w krajach Unii Europejskiej. Linuron obecnie zalecany w ziemniakach i marchwi, był zalecany w czosnku do roku 2011, a oksyfluorofen obecnie zalecany w cebuli - do roku 2010.

Analizując dostępność środków ochrony roślin w innych państwach członkowskich Unii Europejskiej można stwierdzić, że w większości przypadków (poza Bułgarią i Belgią) możliwości chemicznej ochrony czosnku przed chwastami są lepsze niż w Polsce.

\section{Podsumowanie / Summary}

Trudno pozytywnie komentować fakt, że Polska, która jest ważnym producentem wielu warzyw, owoców, ziół i roślin ozdobnych ma tak mało środków służących ochronie upraw małoobszarowych. Przeanalizowane wyżej słabe możliwości ochrony czosnku przed chwastami nie są żadnym wyjątkiem, ale raczej ilustrują pewną prawidłowość (Matyjaszczyk 2012; Matyjaszczyk i Dobrzański
2015; Matyjaszczyk i Dobrzański 2016). W artykule przedstawiono niechemiczne możliwości ograniczania zachwaszczenia w czosnku. Należy jednak podkreślić, że ograniczenie możliwości stosowania chemicznej ochrony powoduje zwiększenie kosztów produkcji (Nowacki 2008). W produkcji bez udziału środków chemicznych, szacuje się, że przy wyższych kosztach uprawy, plony są o około $20 \%$ niższe niż w gospodarstwach konwencjonalnych (Rembiałkowska 2007). Gorsza pozycja konkurencyjna polskich producentów upraw małoobszarowych wynika z faktu, że bez dostępu do odpowiednich środków chemicznej ochrony koszty produkcji w naszym kraju są wyższe, natomiast ceny sprzedaży płodów rolnych w całej Unii Europejskiej utrzymują się na zbliżonym poziomie ze względu na wspólny rynek. Brak środków chemicznych albo ograniczone możliwości rotacji substancji czynnych powodują, że nasi rolnicy są w niekorzystnej sytuacji w stosunku do producentów tych samych upraw z innych państw członkowskich, z którymi konkurują na wspólnym rynku. Rolnikom trudno zrozumieć fakt, że niektóre $\mathrm{z}$ hebicydów zarejestrowanych $\mathrm{w}$ innych państwach Unii Europejskiej do ochrony czosnku, są u nas dopuszczone do obrotu i stosowania, ale ze względu na brak rejestracji ich stosowanie jest wykroczeniem i naruszeniem obowiązującego prawa. Producenci środków ochrony roślin ubiegając się o rejestrację nie zawsze wykazują zainteresowanie uzyskaniem zezwolenia dla gatunków małoobszarowych, takich jak czosnek. Wynika to z różnych powodów, między innymi ze strategii rynkowej, koncentrującej się na rejestracji agrochemikaliów do zastosowań wielkoobszarowych oraz z unikania kosztów badań i rejestracji. Pamiętajmy jednak, że inicjatywa nie leży tylko po stronie producentów środków ochrony roślin. Zgodnie z unijnym Rozporządzeniem 1107/2009 (Rozporządzenie 2009) z wnioskiem o wydanie zezwolenia na stosowanie środka w uprawach małoobszarowych mogą występować instytucje państwowe, placówki naukowe i społeczno-zawodowe, organizacje rolników, izby rolnicze, producenci środków ochrony roślin, a nawet każdy zajmujący się uprawą roślin. Problem braku herbicydów dla upraw małoobszarowych, w tym czosnku, nie rozwiąże się sam i wymaga współdziałania producentów agrochemikaliów, urzędów odpowiedzialnych za rejestrację i innych zainteresowanych.

\section{Literatura / References}

Adamczewski K. 2014. Odporność chwastów na herbicydy. Wydawnictwo Naukowe PWN SA, Warszawa, 275 ss.

Adamczewski K., Dobrzański A. 2008. Znaczenie i możliwości wykorzystania metod agrotechnicznych i niechemicznych do regulowania zachwaszczenia w ekologicznej uprawie roślin. s. 221-241. W: „Poszukiwanie nowych rozwiązań w ochronie upraw ekologicznych” (E. Matyjaszczyk, red.). Instytut Ochrony Roślin - PIB, Poznań, 388 ss.

Agamalian H.S., Kurtz E.A. 1989. Garlic weed competition. California Agriculture. January-February: 11-12.

Ascard J. 1995. Thermal weed control by flaming: Biological and technical aspects. Report 200, Swedish University of Agricultural Science, Alnarp, $61 \mathrm{pp}$.

Babik I., Babik J., Dyśko J., Kaniszewski S., Moraczewski A., Podsiedlik A., Wojtysiak J. 2015. Ściółkowanie. s. 22-27. W: „Rewitalizacja ekosystemu glebowego" (S. Karniszewski, red.). Instytut Ogrodnictwa i Instytut Technologii i Eksploatacji - PIB, 153 ss.

Barańska Z., Sabat T. 1988. Nakłady pracy na produkcję czosnku jarego w 1986 r. Nowości Warzywnicze 20: 69-75.

Bond W., Grundy A.C. 2001. Non chemical weed management in organic farming systems. Weed Research 41: $383-405$.

Chmielewska B. 2011. Wpływ członkostwa Polski w UE na sytuację ekonomiczną małych gospodarstw oraz rozwój przedsiębiorczości na obszarach wiejskich. Problemy Rolnictwa Światowego 11 (26) 4: 56-66.

Databases on registered plant protection products in Europe 2016. http://www.eppo.int/PPPRODUCTS/information/information _ppp.htm [dostęp: 12.09.2016]. 
Dobrzański A. 1988. Zwalczanie chwastów w uprawie czosnku. Nowości Warzywnicze 20: 23-32.

Dobrzański A. 1999. Chwasty w uprawach warzywnych - aktualne problemy i zagrożenia. s. 11-14. W: „Przenikanie gatunków ruderalnych z siedlisk sadowniczych i parkowych do zbiorowisk segetalnych, upraw warzywniczych i rolniczych”. XXIII Krajowa Konferencja Naukowa z cyklu: „Rejonizacja chwastów segetalnych w Polsce”. Instytut Warzywnictwa, Skierniewice, $15-16.07 .1999,68 \mathrm{ss}$.

Dobrzański A. 2008. Rola chwastów zimujących i ozimych w agrofitocenozach upraw warzyw. [The role of winter and overwintering weeds in agrophytocenosis of vegetable crops ]. Zeszyty Naukowe Wydziału Ogrodniczego, Wyższa Szkoła Ekonomiczno-Humanistyczna w Skierniewicach. Zeszyt 8: 85-100.

Dobrzański A., Adamczewski K. 2013. Niechemiczne metody zwalczania chwastów - stan obecny i perspektywy. s. 55-96. W: „Współczesna inżynieria rolnicza - osiągnięcia i nowe wyzwania”. Tom III (R. Hołownicki, M. Kuboń, red.). Polskie Towarzystwo Inżynierii Rolniczej, Drukrol S.C., Kraków, 443 ss.

Dobrzański A., Anyszka Z. 2006. Zastosowanie ściółki z folii biodegradowalnej do regulowania zachwaszczenia w integrowanej i ekologicznej uprawie warzyw. Nowości Warzywnicze 43: 75-80.

Dobrzański A., Anyszka Z., Pałczyński I. 2003. Biomasa chwastów w zależności od gatunku roślin warzywnych i sposobu uprawy. Pamiętnik Puławski 134: 51-58.

Domaradzki K., Praczyk T., Matysiak K. 2003. Prototype of Polish version of Decision Support System for weeds. DIAS Report Plant Production 96, $175 \mathrm{pp}$.

Doruchowski R.W. 2006 Warto uprawiać czosnek. Hortpress, Warszawa, 63 ss.

Duranti A. 1988. Competitive interrelationship between weeds and some Alliaceae (Allium cepa and Allium sativum L.). Proceeding of 11th Pacific Weed Science Society Conference. Taipej, the Republic of China, 29.11-05.12.1987, $117 \mathrm{pp}$.

Fajkowska H., Dobrzański A. 1970. Odchwaszczanie czosnku przy użyciu herbicydów. [Weed control in garlic with the use of herbicides]. Biuletyn Warzywniczy 11: 79-99.

FAO 2007. Garlic. Post-harvest operations. Food and Agriculture Organization of the United Nations, $43 \mathrm{pp}$

Główny Urząd Statystyczny 2012. Charakterystyka gospodarstw rolnych. Powszechny spis rolny 2010. Warszawa, 468 ss.

Główny Urząd Statystyczny 2014. Charakterystyka gospodarstw rolnych w roku 2013. Warszawa, 450 ss.

Golinowska M. 2012. Koszty integrowanej ochrony roślin. [Costs of integrated plant protection]. Progress in Plant Protection/Postępy w Ochronie Roślin 52 (3): 521-526.

Kotlińska T. 1993. Kolekcja genotypów czosnku (Allium sativum L). Ogólnopolska Konferencja „Biologia i agrotechnika czosnku”. Lublin, 21.10.1993: 59-62.

Kotliński S. 2004. Przydatność stosowania ściółek z roślin okrywowych w ograniczaniu chemizacji upraw. [Usefulness of cover crops mulch in limitation of synthetic chemicals applied in plant cultivation]. Progress in Plant Protection/Postępy w Ochronie Roślin 44 (1): $167-175$.

Kucharski M. 2015. Rola adiuwantów doglebowych w ograniczaniu wymywania herbicydów. Warzywa 4: 93-98.

Lauer E. 1953. Über die Keimtemperatur von Ackerunkräutern und deren Einfluß auf die Zusammensetzung von Unkrautgesellschaften. Flora 140: 551-595.

Markow M. 1978. Agrofitocenologia nauka o zbiorowiskach roślinnych. PWRiL, Warszawa, 266 ss.

Matthews J.M. 1994. Management of herbicide resistant weed populations. p. 317-335. In: "Herbicide Resistance in Plants: Biology and Biochemistry" (S.B. Powels, J.A.M. Holtum, eds.). CRC Press, Lewis Publishers, 353 pp.

Matyjaszczyk E. 2012. Aktualne możliwości ochrony wybranych upraw małoobszarowych w Polsce i innych państwach Unii Europejskiej. [Current possibilities of selected minor crops protection in Poland and other European Union countries]. Progress in Plant Protection/Postępy w Ochronie Roślin 52 (1): 167-173.

Matyjaszczyk E., Dobrzański A. 2015. Ochrona rabarbaru (Rheum raponticum L.) przed chwastami w Polsce i innych krajach. [Weed management in rhubarb (Rheum raponticum L.) in Poland and other countries]. Progress in Plant Protection 55 (4): 466-471.

Matyjaszczyk E., Dobrzański A. 2016. Zachwaszczenie upraw szpinaku i problemy z jego ograniczaniem. Zagadnienia Doradztwa Rolniczego 2 (84): 103-113.

Mazowiecki Ośrodek Doradztwa Rolniczego 2016. Kalkulacje kosztów produkcji czerwiec 2016. http://www.modr.mazowsze.pl/ /notowania-i-kalkulacje-cenowe/kalkulacje-kosztow-produkcji [dostęp: 29.08.2016].

Nowacki W. 2008. Porównanie opłacalności upraw konwencjonalnych i ekologicznych na przykładzie ziemniaka. s. 48-62. W: „Poszukiwanie nowych rozwiązań w ochronie upraw ekologicznych” (E. Matyjaszczyk, red.). Instytut Ochrony Roślin - PIB, Poznań, 388 ss.

Orłowski M., Kołota E. 1983. Chemiczne zwalczanie chwastów w uprawie czosnku. Zeszyty Naukowe Akademii Rolniczej w Szczecinie, Rolnictwo 31 (cz. I): 191-203; (cz. II): 207-213.

Orłowski M., Kołota E. 1984. Wpływ niektórych zabiegów agrotechnicznych na plon czosnku. Cz. II. Wpływ terminu gęstości sadzenia na plon czosnku. Biuletyn Warzywniczy 27: 165-175.

Orłowski M., Kołota E. 1993. Czosnek. s. 78-94. W: „Uprawa warzyw”. Wydawnictwo Brasika, Szczecin, 248 ss.

Pałczyński J., Dobrzański A. 1993. Zwalczanie chwastów w uprawie czosnku (Allium sativum L.) sadzonego jesienią. [Weed control in winter garlic (Allium sativum L.)]. Biuletyn Warzywniczy 40: 111-124.

Paszko D., Pawlak J., Jarzyna M., Zmarlicki K. 2015. Integrowana ochrona roślin w opinii producentów owoców jagodowych. Stowarzyszenie Ekonomistów Rolnictwa i Agrobiznesu. Roczniki Naukowe 17 (3): 309-314.

PPDB - Pesticides Properties DataBase 2016. http://sitem.herts.ac.uk/aeru/ppdb/en/ [dostęp: 04.09.2016].

Quasem J.R. 1996. Weed competition in garlic (Allium sativum L.). Journal of Horticultural Science 71 (1): 41-48.

Rahman H.U., Khattak A.M., Sadiq M., Ullah K., Javaria S., Ullah I. 2012. Influence of different weed management practices on yield of garlic crop. Sarhad Journal of Agriculture 28 (2): 213-218.

Rembiałkowska E. 2007. Jakość ziemiopłodów i produktów zwierzęcych w rolnictwie ekologicznym. W: „Możliwości rozwoju rolnictwa ekologicznego w Polsce" (A. Harasim, red.). Studia i Raporty IUNG - PIB: 59-75.

Rola J., Rola H. 2013. 40 lat zespołowych badań nad biologią i rejonizacją chwastów segetalnych w Polsce (1971-2011). Instytut Uprawy Nawożenia i Gleboznawstwa - PIB, Puławy, 331 ss. 
Rola H., Rola J., Zaliwski A. 1999. Monitoring stanu stopnia zachwaszczenia upraw rolniczych. [Monitoring of weed infestation of field crop in Poland]. Progress in Plant Protection/Postępy w Ochronie Roślin 39 (1): 289-297.

Rozporządzenie Parlamentu Europejskiego i Rady (WE) NR 1107/2009 z dnia 21 października 2009 r. dotyczące wprowadzania do obrotu środków ochrony roślin i uchylające dyrektywy Rady 79/117/EWG i 91/414/EWG. Dz. U. UE L 309/1 z dnia 24.11.2009 r.

Rumpel J., Grudzień K. 1984. Folia w warzywnictwie gruntowym. PWRiL, Warszawa, 156 ss.

Siciński J. 2000. Zbiorowiska chwastów upraw warzywnych w rejonie Łęczycy. Acta Universitatis Lodziensis, Folia Biologica et Oecologica 15: 67-79.

Teasdale J.R., Beste C.E., Potts W.E. 1991. Response of weeds to tillage and cover crop residue. Weed Science 39: 195-199.

Termopielnik 2016. http://www.lukomet.pl/termopielnik-pielnik-wielofunkcyjny-p3579 [dostęp: 10.09.2016].

Van der Weide R.Y., Bleker P.O., Achten V.T.J.M., Lotz L.A.P. 2008. Innovation in mechanical weed control in crop rows. Weed Research 48: 215-224.

Wyszukiwarka Środków Ochrony Roślin Ministerstwa Rolnictwa i Rozwoju Wsi 2016. http://www.minrol.gov.pl/Informacje-branzowe/Wyszukiwarka-srodkow-ochrony-roslin/ [dostęp: 29.08.2016].

Zbytek Z., Talarczyk W. 2013. Niechemiczne (mechaniczne) metody zwalczania chwastów dla produkcji ekologicznej. s. 393-419. W: „Współczesna inżynieria rolnicza - osiągnięcia i nowe wyzwania”. Monografia. Tom II (R. Hołownicki, M. Kuboń, red.). Polskie Towarzystwo Inżynierii Rolniczej, Drukrol S.C., Kraków, 421 ss.

Żelaziński T. 2014. Mechaniczne zwalczanie chwastów. Technika sadownicza i warzywnicza 2: 65-72. 